\title{
Pituitary Macroadenoma Presenting as Acromegaly and Subacute Pituitary Apoplexy: Case Report and Literature Review
}

\author{
Artsiom Klimko ${ }^{1}$, Cristina Capatina ${ }^{2,3}$ \\ 1. Division of Physiology and Neuroscience, Carol Davila University of Medicine and Pharmacy, Bucharest, ROU 2. \\ Department of Endocrinology, Carol Davila University of Medicine and Pharmacy, Bucharest, ROU 3. Department of \\ Pituitary and Neuroendocrine Pathology, C.I. Parhon National Institute of Endocrinology, Bucharest, ROU
}

Corresponding author: Cristina Capatina, cristina.capatina@yahoo.com

\begin{abstract}
We report a case of a patient who presented to our endocrinology department for gradual onset with headache, fatigue, and weight loss over the course of one month. On physical examination, the patient showcased coarse facial features, acral enlargement, and other features suggestive of acromegaly. However, despite a clinical picture consistent with this diagnosis, serum growth hormone and insulin-like growth factor 1 were below reference range. Furthermore, secondary adrenal insufficiency, secondary hypothyroidism, and hypogonadotropic hypogonadism were discovered. Imaging revealed a pituitary macroadenoma and after a neurosurgical consult, the patient underwent transsphenoidal hypophysectomy and the suspected diagnosis of subacute pituitary adenoma apoplexy (SPAA) was confirmed via histology of resected tissue. Additionally, we review the literature for other case reports of patients with acromegaly or acromegalic features who underwent pituitary apoplexy to identify patient characteristics, presumed etiologies, and presence of biochemical cure of acromegaly following SPAA.
\end{abstract}

Categories: Endocrinology/Diabetes/Metabolism, Neurosurgery

Keywords: acromegaly, subacute, pituitary apoplexy, macroadenoma, subclinical

\section{Introduction}

Acromegaly is a rare clinical syndrome driven by high serum values of growth hormone (GH) and insulin-like growth factor 1 (IGF-1). Functional pituitary adenomas are the most common cause of acromegaly, and the onset of the disease is characteristically gradual, leading to a substantial delay in diagnosis and treatment $[1,2]$. The purpose of this case report is to detail a rare complication of pituitary adenomas, namely subacute pituitary adenoma apoplexy (SPAA). In contrast to classic pituitary apoplexy, SPAA lacks the features of sudden onset severe headache, visual defects, or ophthalmoplegia, and can therefore present as a diagnostic challenge for clinicians [3,4]. Pituitary apoplexy can be associated with biochemical cure in secreting pituitary adenomas [5-7].

Received 07/31/2020

Review began $08 / 03 / 2020$ Review ended 08/04/2020 Published 08/08/2020

() Copyright 2020

Klimko et al. This is an open access article distributed under the terms of the Creative Commons Attribution License CC-BY 4.0., which permits unrestricted use, distribution, and reproduction in any medium, provided the original author and source are credited.

\section{Case Presentation}

A 41-year-old male patient was admitted to our endocrinology department for $8 \mathrm{~kg}$ weight loss over the past month, accompanied by loss of appetite, profound fatigue, decreased libido, and profuse sweating. He had a history of recurrent sinusitis and one month ago; there was a particularly protracted episode of left frontal and maxillary sinusitis requiring several courses of antibiotic treatment. He also complained of chronic headache that appeared periodically over the past five years.

Clinical examination revealed an asthenic patient with classic acromegalic features, namely mandibular prognathism, broad nose, thickened lips, prominent supraorbital ridges, and thickened skin folds on the scalp. These features were especially conspicuous when compared against photos over the last two decades. The patient also affirmed noticing enlargement of extremities, especially in the form of increasing shoe size, over approximately the last seven years. Surprisingly, paraclinical investigations (Table 1) revealed suppressed levels of GH and IGF-1 and rather than acromegaly, a diagnosis of pituitary insufficiency was made. Blood pressure was 120/60 mmHg without orthostatic hypotension, and heart rate was 56 beats per minute, without pathological changes on electrocardiography. The thyroid gland was also enlarged, and ultrasonography revealed multiple nodular cystic formations. Electrolytes and complete blood count values were within reference range. 


\section{Cureus}

\begin{tabular}{|c|c|c|}
\hline Investigation completed & Reference range & Result of the investigation \\
\hline Nadir growth hormone (post-oral glucose suppression test, $\mathrm{ng} / \mathrm{mL}$ ) & $<1.000$ & $<0.500$ \\
\hline Insulin-like growth factor 1 (ng/mL) & $55-235$ & 167.5 \\
\hline Early morning cortisol ( $\mu \mathrm{g} / \mathrm{dL})$ & $5-25$ & $<0.4$ \\
\hline rastıng serum glucose (mg/dL) & 70-99 & $6 r$ \\
\hline TSH ( $(\mu \mathrm{lU} / \mathrm{mL})$ & $0.5-4.5$ & 0.059 \\
\hline Free T4 (ng/dL) & 9-19 & 11.69 \\
\hline Prolactin (ng/mL) & $2.5-17$ & 0.92 \\
\hline Testosterone (ng/mL) & 1.75-7.81 & $<0.1$ \\
\hline Luteinizing hormone (mlU/mL) & $2-12$ & $<0.2$ \\
\hline Follicle-stimulating hormone (mlU/mL) & $1-12$ & 0.7 \\
\hline
\end{tabular}

\section{TABLE 1: Laboratory results at admission.}

GH: growth hormone; TSH: thyroid-stimulating hormone.

Cranial MRI revealed a pituitary macroadenoma (214 mm x $168 \mathrm{~mm}$ x $147 \mathrm{~mm}$ ) with variable T1/T2 enhancement (Figure 1). The macroadenoma was not invading the cavernous sinus or compressing the optic chiasm and thus, the ophthalmologic exam (including the confrontational visual field testing) was normal. The patient was started on hormone replacement therapy with prednisone, levothyroxine, and testosterone undecanoate by intramuscular injection.
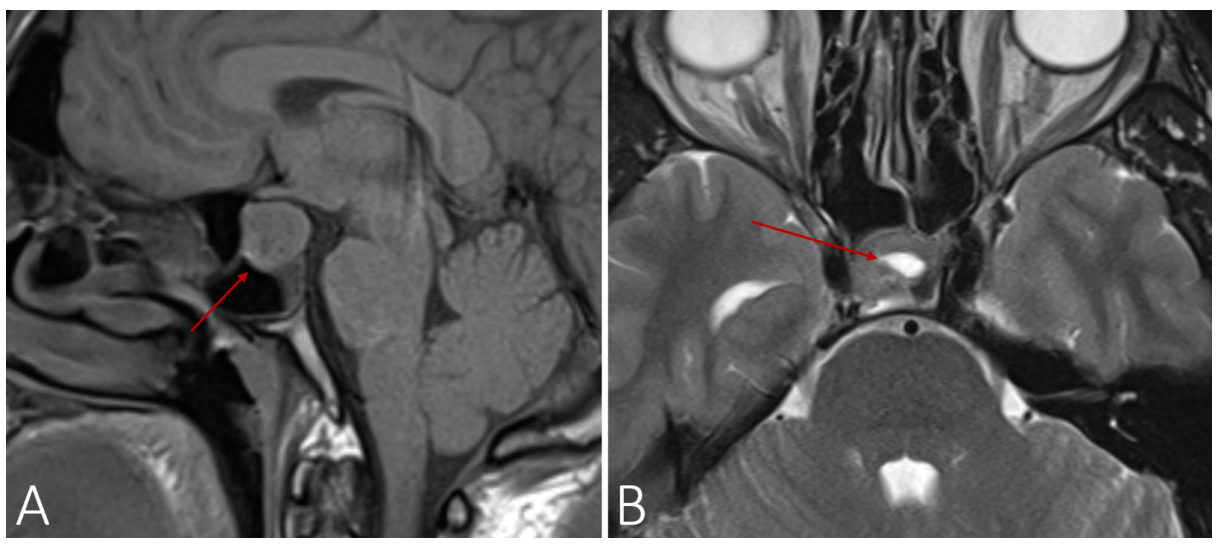

FIGURE 1: Cranial MRI: T1-weighted saggital plane (A) and T2-weighted axial plane (B) demonstrating a pituitary macroadenoma $(214 \mathrm{~mm} \times 168$ $\mathrm{mm} \times 147 \mathrm{~mm}$ ); in the latter image, hyperintense filling (arrow) of the adenoma is also visible, suggesting pituitary apoplexy.

After starting replacement, glucose levels normalized, thus obviating the need to consider an insulinoma as part of multiple endocrine neoplasia type 1. Neurosurgical consult was requested and, one month later, elective transsphenoidal endoscopic resection was conducted for surgical debulking in view of the patient's symptomatology, size of the adenoma, and presence of postero-superior hypothalamic compression. Histopathologic exam of the resected tissue revealed extensive coagulative necrosis and supported the diagnosis of pituitary apoplexy. The low prolactin levels also mirrored this, as low levels are suggestive of massive pituitary necrosis. The postoperative course was uneventful and at the latest follow-up visit 14 months after hypophysectomy, remission of most of the patient's acromegalic features was noted. Control MRI did not show any new expansive lesions in the sellar region (Figure 2), as was confirmed by annual GH and IGF-1 assays. 


\section{Cureus}
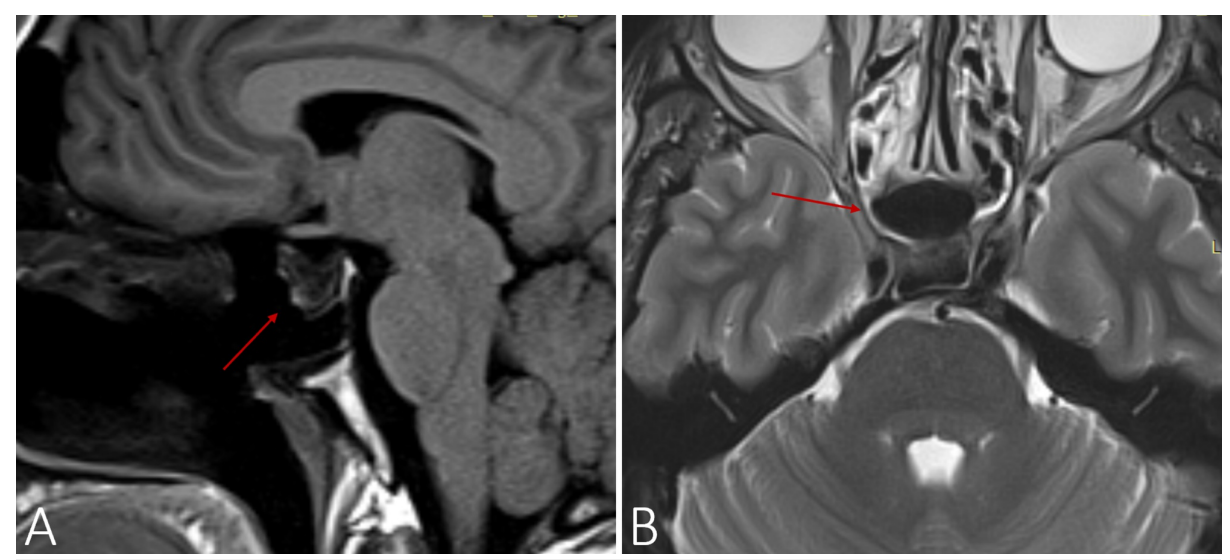

FIGURE 2: Cranial MRI: T1-weighted saggital plane (A) and T2-weighted axial plane (B) one year after transspnehoidal hypophysectomy, demonstrating an empty sella (arrow) and a confirming absence of new expansive lesions in the sellar region.

\section{Discussion}

In this case report, we presented a patient with subacute pituitary apoplexy leading to the biochemical cure of a previously undiagnosed GH-secreting pituitary adenoma and pituitary insufficiency. The pituitary necrosis was so extended that it completely destroyed the cells of the pituitary adenoma and made the precise diagnosis by biochemical tests or tumor immunohistochemistry impossible. In a recent review of population studies, Lavrentaki et al. found the annual incidence of acromegaly to range between 0.2 and 1.1 cases per 100,000 people, with median age of diagnosis ranging from 40.5 to 47 years, which is consistent with our patient [8]. GH-secreting pituitary adenomas are the most common cause of acromegaly and as recent evidence suggests, such tumors have wide clinicopathologic variation [2]. For example, sparsely granulated somatotroph tumors, which are found in $15 \%-35 \%$ of patients with acromegaly, are associated with subtle clinical features and relatively mild elevations in GH/IGF-1. This intertumoral heterogeneity explains why not all patients develop a rapidly progressive phenotype and provides insight into the substantial average diagnostic delay of eight years that is reported in many population studies $[1,8]$.

Delay in diagnosis also likely explains why approximately $75 \%$ of somatotroph adenomas are detected as macroadenomas (adenoma $>10 \mathrm{~mm}$ ) at the time of diagnosis [1,8]. This delay in diagnosis and expected tumor size were also findings consistent in our case. Long-term exposure to supraphysiologic levels of GH/IGF-1 leads to overgrowth of tissues, visceral organs, and systemic complications, like cardiovascular disease, which is the main cause of mortality [9]. Ezzat et al. conducted a prospective study on 500 patients and the clinical features with a prevalence over $50 \%$ of their cohort are presented in Table 2 [10]. Excessive acral growth, coarsening of facial features, and generalized soft tissue swelling were the most common features and all three were found in our patient, supporting the clinical diagnosis of acromegaly, despite the lack of confirmatory lab findings. We interpret the lack of biochemical confirmation in our case as the result of the extensive necrosis of the tumoral tissue. Current treatment options include transsphenoidal surgery, radiotherapy, or medical therapy with dopamine agonists, somatostatin analogs, or GH receptors antagonists. Although skeletal and articular changes are permanent, up to $70 \%$ of patients experience resolution of other systemic symptoms and metabolic complications [9]. 


\section{Cureus}

\begin{tabular}{|c|c|c|}
\hline Prevalence & Signs and symptoms & Presence in our patient \\
\hline $98 \%$ & Acral growth & Yes \\
\hline $97 \%$ & Facial feature enlargement & Yes \\
\hline $90 \%$ & Soft tissue swelling & Yes \\
\hline $73 \%$ & Excessive perspiration & Yes \\
\hline $57 \%$ & Headache & Yes \\
\hline $53 \%$ & Peripheral neuropathy & No \\
\hline
\end{tabular}

TABLE 2: Common signs and symptoms of acromegaly and their presence/absence in our patient.

The second component of this case is the appearance of SPAA. Classic pituitary apoplexy is defined as acute hemorrhage into the pituitary gland and as an entity, it is a life-threatening acute clinical syndrome, which, despite all the attention given to it, is exceedingly rare. In a retrospective analysis of 799 cases of pituitary adenomas, Bonicki et al. found 113 (14\%) cases with histological evidence of infarction/necrosis and only a subset of 39 cases (34.5\%) qualified for the diagnosis of pituitary apoplexy [4]. SPAA is more common and is defined by presence of hemorrhage and necrosis within the tumor in the absence of sudden onset severe headache, visual defects, or ophthalmoplegia [3,4]. In their retrospective analysis of 185 patients with SPAA, Zhang et al. noted the most common clinical presentation to include visual disturbances (76.7\%), hyperprolactinemia (63.2\%), and hypopituitarism (54.6\%) [3]. However, in their cohort the majority of pathologies were constituted by prolactinomas (51.9\%) and non-functional pituitary adenomas (37.0\%), which is somewhat discordant with literature, where the most frequent preexisting tumor types are reported to be non-functioning pituitary adenomas, followed by prolactinomas and GH-secreting adenomas [5].

To further explore the association between acromegaly and pituitary apoplexy, a search of the PubMed and Scopus databases was done using the keywords "pituitary apoplexy," "subacute apoplexy," "subclinical apoplexy," and "acromegaly" to identify relevant case reports published in the last 10 years. The keywords were identified in either title/abstract or as Medical Subject Heading (MeSH) terms. Of the 14 case reports found, 4 were excluded either due to being unrelated or written in a language other than English, resulting in 10 case reports which were included in our review and are presented in Table 3. The table structure was adapted from the article by Fraser et al. and including ours, 11 patients were reviewed [11]. 


\section{Cureus}

\begin{tabular}{|c|c|c|c|c|c|c|}
\hline $\begin{array}{l}\text { Author and } \\
\text { date }\end{array}$ & Sex and age & $\begin{array}{l}\text { Apoplexy } \\
\text { type }\end{array}$ & $\begin{array}{l}\text { Presenting signs and } \\
\text { symptoms }\end{array}$ & $\begin{array}{l}\text { Presumed } \\
\text { trigger }\end{array}$ & $\begin{array}{l}\text { Effect on } \\
\text { GH/IGF-1 }\end{array}$ & $\begin{array}{l}\text { Effect on other pituitary } \\
\text { hormones }\end{array}$ \\
\hline $\begin{array}{l}\text { Wildemberg } \\
\text { et al., } 2012 \\
\text { [12] }\end{array}$ & Male, 40 & Acute & Severe headache and vomiting & $\begin{array}{l}\text { Dengue } \\
\text { hemorrhagic } \\
\text { fever }\end{array}$ & $\begin{array}{l}\text { No effect } \\
\text { (elevated } \\
\text { GH/IGF-1 at } \\
\text { presentation) }\end{array}$ & $\begin{array}{l}\text { Transient hypogonadotropic } \\
\text { hypogonadism and } \\
\text { hyperprolactinemia }\end{array}$ \\
\hline $\begin{array}{l}\text { Cinar et al., } \\
2013 \text { [13] }\end{array}$ & Male, 38 & Acute & $\begin{array}{l}\text { Severe headache, malaise, } \\
\text { nausea, vomiting }\end{array}$ & $\begin{array}{l}\text { Insulin } \\
\text { therapy or } \\
\text { MRI IV } \\
\text { contrast }\end{array}$ & $\begin{array}{l}\text { Decreased (GH } \\
2.72 \mu \mathrm{g} / \mathrm{L})\end{array}$ & $\begin{array}{l}\text { Panhypopituitarism (including } \\
\text { diabetes insipidus) }\end{array}$ \\
\hline $\begin{array}{l}\text { Nganga et } \\
\text { al., } 2013[6]\end{array}$ & Female, 31 & Subacute & $\begin{array}{l}\text { One year of headache, irregular } \\
\text { menses, and progressive } \\
\text { decline in vision }\end{array}$ & Idiopathic & $\begin{array}{l}\text { No effect } \\
\text { (elevated } \\
\text { GH/IGF-1 at } \\
\text { presentation) }\end{array}$ & Hyperprolactinemia \\
\hline $\begin{array}{l}\text { Mir et al., } \\
2013[14]\end{array}$ & Male, 63 & Acute & $\begin{array}{l}\text { Severe headache, vomiting, } \\
\text { decreased consciousness (GCS } \\
\text { 10), and right-sided CN III palsy }\end{array}$ & Idiopathic & Not available & $\begin{array}{l}\text { Secondary adrenal insufficiency } \\
\text { and central hypothyroidism }\end{array}$ \\
\hline $\begin{array}{l}\text { Jiang et al., } \\
2013 \text { [15] }\end{array}$ & Male, 49 & Acute & Severe headache and DKA & Diabetes & $\begin{array}{l}\text { No effect } \\
\text { (elevated } \\
\text { GH/IGF-1 at } \\
\text { presentation) }\end{array}$ & $\begin{array}{l}\text { No effect (all other hormones } \\
\text { within reference range) }\end{array}$ \\
\hline $\begin{array}{l}\text { Villar-Taibo } \\
\text { et al., } 2014 \\
\text { [16] }\end{array}$ & Female, 51 & Acute & $\begin{array}{l}\text { Severe headache, nausea, } \\
\text { vomiting, phonophobia, } \\
\text { photophobia }\end{array}$ & Meningitis & $\begin{array}{l}\text { Decreased (GH } \\
0.6 \mathrm{ng} / \mathrm{mL} \text {, } \\
\text { IGF-1 } 72.5 \\
\mathrm{ng} / \mathrm{mL})\end{array}$ & $\begin{array}{l}\text { Panhypopituitarism (including } \\
\text { diabetes insipidus) }\end{array}$ \\
\hline $\begin{array}{l}\text { Roerink et } \\
\text { al., } 2014 \\
\text { [17] }\end{array}$ & $\begin{array}{l}\text { Male, } 46 \text { (FTM } \\
\text { transformation) }\end{array}$ & Acute & $\begin{array}{l}\text { Severe headache, nausea, } \\
\text { vomiting, blurred vision }\end{array}$ & Idiopathic & $\begin{array}{l}\text { No effect } \\
\text { (elevated } \\
\text { GH/IGF-1 at } \\
\text { presentation) }\end{array}$ & $\begin{array}{l}\text { Secondary adrenal insufficiency } \\
\text { and secondary hypothyroidism }\end{array}$ \\
\hline $\begin{array}{l}\text { Roerink et } \\
\text { al., } 2015 \text { [7] }\end{array}$ & Male, 41 & Subacute & $\begin{array}{l}\text { Episode of severe neck pain } \\
\text { with fatigue and presyncope } \\
\text { three months prior }\end{array}$ & Idiopathic & $\begin{array}{l}\text { Decreased (GH } \\
1.2 \mathrm{ng} / \mathrm{mL} \text {, } \\
\text { IGF-1 100.9 } \\
\mathrm{ng} / \mathrm{mL} \text { ) }\end{array}$ & $\begin{array}{l}\text { Hypogonadotropic } \\
\text { hypogonadism and partial } \\
\text { secondary adrenal insufficiency }\end{array}$ \\
\hline $\begin{array}{l}\text { Kumar et } \\
\text { al., } 2016 \\
{[18]}\end{array}$ & Male, 18 & Acute & $\begin{array}{l}\text { Severe headache, vomiting, } \\
\text { blurred vision }\end{array}$ & Idiopathic & $\begin{array}{l}\text { No effect } \\
\text { (elevated } \\
\text { GH/IGF-1 at } \\
\text { presentation) }\end{array}$ & $\begin{array}{l}\text { Secondary adrenal insufficiency } \\
\text { and secondary hypothyroidism }\end{array}$ \\
\hline $\begin{array}{l}\text { Patra et al. } \\
2017 \text { [19] }\end{array}$ & Male, 36 & Acute & Severe headache & $\begin{array}{l}\text { Polycythemia } \\
\text { vera }\end{array}$ & $\begin{array}{l}\text { No effect } \\
\text { (elevated } \\
\text { GH/IGF-1 at } \\
\text { presentation) }\end{array}$ & $\begin{array}{l}\text { Secondary adrenal insufficiency } \\
\text { and secondary hypothyroidism }\end{array}$ \\
\hline $\begin{array}{l}\text { Current } \\
\text { case }\end{array}$ & Male, 41 & Subacute & $\begin{array}{l}\text { Headache, fatigue, weight loss, } \\
\text { decreased libido over past } \\
\text { month }\end{array}$ & Idiopathic & $\begin{array}{l}\text { Decreased (GH } \\
0.05 \mathrm{ng} / \mathrm{mL} \text {, } \\
\text { IGF-1 } 167.5 \\
\mathrm{ng} / \mathrm{mL} \text { ) }\end{array}$ & $\begin{array}{l}\text { Secondary adrenal insufficiency, } \\
\text { secondary hypothyroidism, and } \\
\text { hypogonadotropic } \\
\text { hypogonadism }\end{array}$ \\
\hline
\end{tabular}

\section{TABLE 3: Cases published in the last 10 years describing co-occurrence of acromegaly and}

pituitary apoplexy.

GH: growth hormone; IGF-1: insulin-like growth factor 1; IV: intravenous; GCS: Glasgow coma scale; CN: cranial nerve; DKA: diabetic ketoacidosis; FTM: female to male.

The average age of the patients was 41.2 years (range 18-63), and of the eleven patients, nine were male and two were female. The clinical picture of the eight patients diagnosed with pituitary apoplexy was dominated by severe headache and nausea/vomiting. The proposed mechanism of pituitary apoplexy likely involves 
friability and increased fenestrations of neovasculature supplying the tumor, ischemia of the tumor due to mismatch between demand and supply, and compression of vessels supplying the tumor against the diaphragma sellae by the enlarging tumor $[3,20]$. This proposed mechanism, in combination with predisposing risk factors, is already well established but the precise trigger for apoplexy remains poorly understood and in the majority of the cases that were included in our review the precipitating factor was idiopathic. For the three patients with SPAA, the clinical picture is much less specific and especially if other confounding variables are present (such as testosterone therapy for gender transformation, as in the case report by Roerink et al.), the correct diagnosis can be more difficult to make [17].

For 10 patients, the values of GH and IGF-1 after apoplexy, but prior to undergoing surgery, were available and were not suppressed in six patients. We must stress that, in our patient, we did not find definitive biochemical proof of acromegaly, but this diagnosis is highly probably due to the presence of progressive clinical features which began to improve after the pituitary apoplexy event and surgical treatment. Analogously suppressed levels of GH and IGF-1 were found in two other case reports of SPAA [6,7]. Six patients still had increased levels of GH/IGF-1 and would be consistent with literature, where it is reported that the majority of GH-secreting pituitary adenomas remain functional after apoplexy [5]. All patients in our review were treated with transsphenoidal surgery, although patients with gradual evolution and a lack of severe, progressive neuro-ophthalmic signs (or other clinical signs which would be indications for neurosurgical decompression) can be managed conservatively.

\section{Conclusions}

Patients with acromegaly or pathognomonic features may present with decreased levels of GH/IGF-1, and in these situations, a high index of suspicion must be maintained for subacute pituitary apoplexy by clinicians. Subacute pituitary apoplexy is more common than classic pituitary apoplexy, and a tepid emergence of nonspecific symptoms, such as headache, fatigue, and weight loss, should tip clinicians off. The co-occurrence of pituitary insufficiency with SPAA is high and remission of acromegalic features in these patients is likely. However, for the patients in our review who presented with acute apoplexy, GH secretion was more likely to persist despite the apoplexy of the adenoma.

\section{Additional Information \\ Disclosures}

Human subjects: Consent was obtained by all participants in this study. Conflicts of interest: In compliance with the ICMJE uniform disclosure form, all authors declare the following: Payment/services info: All authors have declared that no financial support was received from any organization for the submitted work. Financial relationships: All authors have declared that they have no financial relationships at present or within the previous three years with any organizations that might have an interest in the submitted work. Other relationships: All authors have declared that there are no other relationships or activities that could appear to have influenced the submitted work.

\section{References}

1. Fernandez A, Karavitaki N, Wass JA: Prevalence of pituitary adenomas: a community-based, cross-sectional study in banbury (oxfordshire, uk). Clin Endocrinol. 2010, 72:377-382. 10.1111/j.1365-2265.2009.03667.x

2. Akirov A, Asa SL, Amer L, Shimon I, Ezzat S: The clinicopathological spectrum of acromegaly . J Clin Med. 2019, 8:1962. 10.3390/jcm8111962

3. Zhang F, Chen J, Lu Y, Ding X: Manifestation, management and outcome of subclinical pituitary adenoma apoplexy. J Clin Neurosci. 2009, 16:1273-1275. 10.1016/j.jocn.2009.01.003

4. Bonicki W, Kasperlik-Załuska A, Koszewski W, Zgliczyński W, Wisławski J: Pituitary apoplexy: endocrine, surgical and oncological emergency. Incidence, clinical course and treatment with reference to 799 cases of pituitary adenomas. Acta Neurochir. 1993, 120:118-122. 10.1007/bf02112028

5. Capatina C, Inder W, Karavitaki N, Wass JA: Management of endocrine disease: pituitary tumour apoplexy. Eur J Endocrinol. 2015, 172:179-190. 10.1530/eje-14-0794

6. Nganga HK, Lubanga RP: Pituitary macroadenoma presenting with pituitary apoplexy, acromegaly and secondary diabetes mellitus - a case report. Pan Afr Med J. 2013, 15:39. 10.11604/pamj.2013.15.39.2054

7. Roerink SH, van Lindert EJ, van de Ven AC: Spontaneous remission of acromegaly and cushing's disease following pituitary apoplexy: two case reports. Neth J Med. 2015, 73:242-246.

8. Lavrentaki A, Paluzzi A, Wass JA, Karavitaki N: Epidemiology of acromegaly: review of population studies . Pituitary. 2017, 20:4-9. 10.1007/s11102-016-0754-X

9. Gadelha MR, Kasuki L, Lim DST, Fleseriu M: Systemic complications of acromegaly and the impact of the current treatment landscape: an update. Endocr Rev. 2019, 40:268-332. 10.1210/er.2018-00115

10. Ezzat S, Forster MJ, Berchtold P, Redelmeier DA, Boerlin V, Harris AG: Acromegaly. Clinical and biochemical features in 500 patients. Medicine. 1994, 73:233-240.

11. Fraser LA, Lee D, Cooper P, Van Uum S: Remission of acromegaly after pituitary apoplexy: case report and review of literature. Endocr Pract. 2009, 15:725-731. 10.4158/ep09126.Crr

12. Wildemberg LE, Neto LV, Niemeyer P, Gasparetto EL, Chimelli L, Gadelha MR: Association of dengue hemorrhagic fever with multiple risk factors for pituitary apoplexy. Endocr Pract. 2012, 18:97-101. 10.4158/ep11341.Cr

13. Cinar N, Metin Y, Dagdelen S, Ziyal MI, Soylemezoglu F, Erbas T: Spontaneous remission of acromegaly after infarctive apoplexy with a possible relation to MRI and diabetes mellitus. Neuro Endocrinol Lett. 2013, 


\section{Cureus}

34:339-342.

14. Mir SA, Masoodi SR, Bashir MI, Wani AI, Farooqui KJ, Kanth B, Bhat AR: Dissociated hypopituitarism after spontaneous pituitary apoplexy in acromegaly. Indian J Endocrinol Metab. 2013, 17:102-104. 10.4103/22308210.119518

15. Jiang HJ, Hung WW, Hsiao PJ: A case of acromegaly complicated with diabetic ketoacidosis, pituitary apoplexy, and lymphoma. Kaohsiung J Med Sci. 2013, 29:687-690. 10.1016/j.kjms.2013.08.002

16. Villar-Taibo R, Ballesteros-Pomar MD, Vidal-Casariego A, Alvarez-San Martín RM, Kyriakos G, CanoRodríguez I: Spontaneous remission of acromegaly: apoplexy mimicking meningitis or meningitis as a cause of apoplexy?. Arq Bras Endocrinol Metabol. 2014, 58:76-80. 10.1590/0004-2730000002701

17. Roerink S, Marsman D, van Bon A, Netea-Maier R: A missed diagnosis of acromegaly during a female-tomale gender transition. Arch Sex Behav. 2014, 43:1199-1201. 10.1007/s10508-014-0309-z

18. Kumar S, Sharma S: Pituitary apoplexy causing spontaneous remission of acromegaly following long-acting octreotide therapy: a rare drug side effect or just a coincidence. Oxf Med Case Reports. 2016, 2016:81-83. 10.1093/omcr/omw009

19. Patra S, Biswas SN, Datta J, Chakraborty PP: Hypersomatotropism induced secondary polycythaemia leading to spontaneous pituitary apoplexy resulting in cure of acromegaly and remission of polycythaemia: 'The virtuous circle'. BMJ Case Rep. 2017, 2017:bcr2017222669. 10.1136/bcr-2017-222669

20. Wang XL, Dou JT, Lü ZH, et al.: Spontaneous remission of acromegaly or gigantism due to subclinical apoplexy of pituitary growth hormone adenoma. Chin Med J (Engl). 2011, 124:3820-3823. 